\title{
HUBUNGAN PENGETAHUAN DENGAN STATUS GIZI IBU HAMIL DI PUSKESMAS TANJUNG PINANG KOTA JAMBI
}

\author{
Elisa Murti Puspitaningrum
}

Akademi Kebidanan Jakarta Mitra Sejahtera Jambi email : elisa_mpn@ymail.com

\begin{abstract}
Abstrak
Kekurangan energi kronik (KEK) merupakan salah satu masalah status gizi pada ibu hamil. Jumlah ibu hamil yang menderita KEK di Indonesia mengalami peningkatan dari tahun 2007 sampai 2013, yaitu sebesar 15,7\%. Data di Puskesmas Tanjung Pinang pada tahun 2015 terdapat 6,60\% ibu hamil yang menderita KEK. Penelitian ini bertujuan untuk mengetahui hubungan pengetahuan dengan status gizi pada ibu hamil di Puskesmas Tanjung Pinang Kota Jambi tahun 2016. Penelitian ini bersifat deskriptif korelasi dengan desain cross sectional. Populasi dalam penelitian ini adalah seluruh ibu hamil yang memeriksakan kehamilan di Puskesmas Tanjung Pinang tahun 2016. Sampel berjumlah 62 responden dengan teknik Quota sampling. Pengumpulan data menggunakan data primer dan analisis data menggunakan Chi Square dengan $\alpha=0,05$. Hasil penelitian menunjukkan bahwa mayoritas responden memiliki status gizi baik yaitu 51 ibu hamil (82,3\%) dan minoritas responden yang memiliki status gizi kurang yaitu 11 ibu hamil. Pengetahuan tentang gizi pada ibu hamil, 31 responden (50\%) memiliki pengetahuan baik. Berdasarkan uji Chi Square, ada hubungan pengetahuan dengan status gizi ibu hamil di Puskesmas Tanjung Pinang Kota Jambi. $(p=0,00)$.
\end{abstract}

Kata kunci : status gizi, pengetahuan, kekurangan energi kronik, gizi ibu hamil

\begin{abstract}
Chronic energy deficiency is one of the problem of nutrition status in pregnant women. The number of pregnant women who suffered from chronic energy deficiency in Indonesia had increased from 2007 until 2013, that amounted to 15,7\%. Data of Tanjung Pinang Health Center 2015 showed that there are 6,60\% of pregnant women suffering from chronic energy deficiency. The purpose of this study was to determine the correlation between knowledge and nutrition statusof pregnant woman in Tanjung Pinang Primary Health Center by 2016. This reseach used descriptive correlation study with cross sectional design. The population of study was pregnant women who visited Tanjung Pinang Health Center during 2016. There were 62 respondents employed as the sample with Quota Sampling technique. This study used primary data in data collection and Chi Square Test in data analysis with the result $\alpha=0.05$. The results of study indicated that 51 respondents $(82,3 \%)$ having good nutrition status while the other 11 respondents were in contrast. In accordance with knowledge level, 31 respondents (50\%) having good knowledge. Based on Chi Square test there was a correlation between knowledge and pregnant women's nutrition status in Tanjung Pinang Health Center of Jambi City $(p=0,00)$.
\end{abstract}

Keywords: nutrition status, knowledge, chronic energy deficiency, nutrition of pregnant women

\section{PENDAHULUAN}

Program kesehatan ibu dan anak merupakan salah satu program pokok di Puskesmas yang mendapat prioritas tinggi, mengingat kelompok ibu hamil, menyusui, bayi dan anak merupakan kelompok yang sangat rentan terhadap kesakitan dan kematian (UNICEF, 2012). Masalah gizi di Indonesia merupakan hal yang sangat kompleks dan sangat penting untuk segera diatasi. Empat masalah gizi utama di 
Indonesia adalah Kekurangan Energi Kronik (KEK), Gangguan Akibat Kekurangan Yodium (GAKY), Kekurangan Vitamin A (KVA), Anemia Gizi Besi (AGB). KEK pada ibu hamil merupakan suatu keadaan dimana status gizi seseorang buruk disebabkan karena ketidakseimbangan antara asupan untuk pemenuhan kebutuhan dan pengeluaran energi (Arisman, 2007).

Sasaran ibu hamil yang mengalami KEK di Indonesia dianggap suatu masalah kesehatan jika jumlahnya $\geq 10 \%$. Seseorang yang mengalami KEK biasanya memiliki status gizi kurang. Status gizi pada Wanita Usia Subur (WUS) dan ibu hamil dapat digambarkan dengan melakukan pengukuran Lingkar Lengan Atas (LILA) untuk mengetahui resiko KEK dengan batas ambang LILA $\geq 23,5 \mathrm{~cm}$ (Departemen Gizi dan Kesehatan Masyarakat, 2013).

Masih tingginya kejadian KEK merupakan salah satu masalah yang berhubungan dengan status gizi pada wanita hamil dan WUS. Jumlah penderita KEK pada ibu hamil dan WUS yang berumur 15-49 tahun, dari tahun ke tahun mengalami peningkatan berdasarkan indikator dari pengukuran LILA. Data yang tercatat oleh riset kesehatan dasar (Riskesdas) dari tahun 2007-2013, di Indonesia persentase KEK pada wanita hamil naik sebesar $15,1 \%$ sedangkan persentase KEK pada WUS umur 15-49 tahun juga mengalami kenaikan sebesar $15,7 \%$. Persentase KEK wanita hamil di Indonesia tahun 2013 sebesar 24,2\% dan persentase KEK pada WUS umur 15-49 tahun sebesar 20,8\% (Kemenkes RI, 2013).

Persentase KEK pada ibu hamil dan WUS umur 15-49 tahun terendah ada di provinsi Bali dan tertinggi di provinsi Nusa Tenggara Timur (NTT). Persentase KEK ibu hamil di provinsi Bali sebesar 10,1\% sedangkan untuk persentase WUS adalah sebesar $14 \%$. Jika dibandingkan dengan provinsi NTT, persentase KEK pada ibu hamil adalah sebesar 45,5\% sedangkan persentase KEK pada WUS yaitu sebesar 46,5\%. Provinsi Jambi, persentase KEK pada ibu hamil dan WUS berada di bawah angka nasional (Kemenkes RI, 2013).

Menurut penelitian Sandjaja bahwa persentase ibu hamil yang KEK di Indonesia berdasarkan indikator tinggi badan didapatkan, bahwa ibu hamil yang memiliki tinggi badan $165 \mathrm{~cm}$ atau lebih, memiliki risiko mengalami KEK 12,8 \%. Ibu hamil dengan tinggi badan kurang dari $140 \mathrm{~cm}$, berisiko mengalami KEK sebesar 37,4\% (Sandjaja, 2009).

Sasaran ibu hamil di kota Jambi tahun 2013 dari 20 puskesmas adalah sebanyak 14.095 orang dengan persentase ibu hamil yang KEK sebesar 4,44\%. Jumlah ibu hamil dengan KEK tertinggi di kota Jambi pada tahun 2013 berada di wilayah kerja Puskesmas Simpang IV Sipin yaitu sebesar 4,1\% dari 1.288 ibu hamil. Jumlah ibu hamil KEK di puskesmas Tanjung Pinang sebesar 2,95\% dari 1.419 ibu hamil (Dinas Kesehatan Kota Jambi, 2013).

Tahun 2014, sasaran ibu hamil di kota Jambi sebanyak 14.611 ibu hamil dengan jumlah ibu hamil yang KEK sebesar 3,56\%. Jumlah ibu hamil dengan KEK tertinggi di tahun 2014 berada di puskesmas Kebun Kopi sebesar 17,97\% dari 495 ibu hamil. Ibu hamil yang KEK di puskesmas Tanjung Pinang sebesar 6,60\% dari 939 ibu hamil (Dinas Kesehatan Kota Jambi, 2014).

Salah satu faktor yang menyebabkan ibu hamil mengalami KEK adalah kurangnya pengetahuan ibu hamil dalam menentukan nutrisi yang baik selama kehamilan. Asupan nutrisi pada ibu hamil sebaiknya harus mengandung energi, protein, vitamin, mineral, asam folat, zat besi, kalsium dimana hal itu sangat dibutuhkan dalam proses perkembangan janin. Status gizi selama kehamilan sangat berpengaruh terhadap proses kelahiran bayinya nanti. Ibu dengan kurang gizi dapat meningkatkan terjadinya resiko keguguran, kematian perinatal (kematian janin usia gestasi 22 minggu sampai usia 1 minggu pascalahir) dan neonatal (bayi usia 0-28 hari). Beberapa penelitian yang dilakukan di negara berkembang bahwa separuh dari penyebab terjadinya Berat Bayi Lahir Rendah (BBLR) adalah status gizi ibu, termasuk tinggi badan ibu, berat badan ibu sebelum kehamilan dan penambahan berat badan selama kehamilannya (Sulistyoningsih, 2011).

Berdasarkan survey awal yang dilakukan terhadap 8 ibu hamil di Puskesmas Tanjung Pinang Kota Jambi, diperoleh 3 orang $(38,46 \%)$ jarang mengkonsumsi makanan yang bergizi dan lengkap, seperti mengkonsumsi nasi, sayur, lauk tanpa susu, atau nasi dan lauk saja tanpa sayur dan buah. 2 orang (25\%) mengatakan jarang makan 
sayur. Tujuan penelitian ini adalah untuk mengetahui hubungan antara pengetahuan ibu hamil dengan status gizi ibu hamil di Puskesmas Tanjung Pinang Kota Jambi Tahun 2016.

\section{METODE PENELITIAN}

Desain penelitian yang digunakan adalah penelitian deskriptif korelasi, yang bertujuan untuk menjelaskan hubungan antara variabel bebas dengan variabel terikat, yaitu hubungan pengetahuan ibu dengan status gizi ibu hamil di Puskesmas Tanjung Pinang Kota Jambi tahun 2016.

Populasi dalam penelitian ini adalah seluruh ibu hamil yang memeriksakan kehamilan di Puskesmas Tanjung Pinang tahun 2016. Sampel berjumlah 62 responden dengan menggunakan teknik Quota sampling, yaitu dengan cara menetapkan sejumlah anggota sampel secara quotum atau jatah (Arikunto, 2010). Penelitian dilakukan pada bulan Mei 2016. Pengumpulan data menggunakan data primer, yaitu pengisian kuesioner. Analisis data menggunakan analisis Chi Square dengan $\alpha=0,05$.

\section{HASIL DAN PEMBAHASAN}

\section{Pengetahuan Ibu}

Distribusi frekuensi berdasarkan Pengetahuan Ibu disajikan pada tabel berikut ini:

Tabel 1. Distribusi Frekuensi Berdasarkan Pengetahuan Ibu tentang Gizi Ibu Hamil di Puskesmas Tanjung Pinang Kota Jambi tahun 2016

\begin{tabular}{cccc}
\hline \multirow{2}{*}{ No } & \multirow{2}{*}{ Pengetahuan } & \multicolumn{2}{c}{ Distribusi } \\
\cline { 3 - 4 } & & $\mathrm{F}$ & $\%$ \\
\hline 1. & Kurang baik & 18 & 29 \\
2. & Cukup & 13 & 21 \\
3. & Baik & 31 & 50 \\
\hline \multicolumn{2}{r}{ Jumlah } & 62 & 100 \\
\hline
\end{tabular}

Berdasarkan table 1 diperoleh informasi bahwa dari 62 responden, sebanyak 31 responden $(50 \%)$ memiliki pengetahuan yang baik tentang gizi ibu hamil. Dengan memiliki pengetahuan yang baik maka seorang individu akan berusaha menerapkan pengetahuan tersebut ke dalam praktek kehidupannya, seperti pemenuhan gizi seimbang selama kehamilan (Notoadmodjo, 2010).
Pengetahuan yang baik pada gizi seseorang membuat orang tersebut akan semakin memperhitungkan jumlah dan jenis makanan yang dipilihnya untuk dikonsumsi. Ibu hamil yang memiliki pengetahuan gizi kurang akan berperilaku memilih makanan yang menarik panca indra dan tidak melakukan pilihan berdasarkan nilai gizi makanan tersebut. Sebaliknya mereka yang memiliki pengetahuan baik cenderung lebih banyak menggunakan rasional dan pengetahuan tentang nilai gizi makanan tersebut.

Hal ini sejalan dengan pendapat Astri (2011) bahwa pengetahuan yang dimiliki seorang ibu akan mempengaruhi dalam pengambilan keputusan dan juga berpengaruuh pada perilakunya. Ibu dengan pengetahuan gizi yang baik kemungkinan akan memberikan gizi yang cukup bagi bayinya. Hal ini terlebih lagi jika seorang ibu tersebut memasuki masa ngidam, dimana perut rasanya tidak ingin diisi, mual dan rasa tidak karuan. Walaupun dalam kondisi yang demikian jika seseorang memiliki pengetahuan yang baik maka ia akan berupaya untuk memenuhi kebutuhan gizinya dan juga bayinya.

\section{Status Gizi Ibu Hamil}

Distribusi frekuensi berdasarkan Status Gizi Ibu Hamil disajikan pada tabel berikut ini :

Tabel 2. Distribusi Frekuensi Berdasarkan Status Gizi Ibu Hamil di Puskesmas Tanjung Pinang Kota Jambi

\begin{tabular}{clcc}
\hline \multirow{2}{*}{ No } & \multirow{2}{*}{ Penilaian Status Gizi } & \multicolumn{2}{c}{ Distribusi } \\
\cline { 3 - 4 } & & $\mathrm{F}$ & $\%$ \\
\hline 1 & $\begin{array}{l}\text { Status Gizi Kurang } \\
\text { (LILA <23,5 cm) }\end{array}$ & 11 & 17,7 \\
2 & $\begin{array}{l}\text { Status Gizi Baik } \\
\text { (LILA } \geq 23,5 \mathrm{~cm})\end{array}$ & 51 & $82,3 \%$ \\
\hline & Berdasarkan tabel & 2 & dapat
\end{tabular}
disimpulkan bahwa dari 62 orang ibu hamil, mayoritas responden memiliki Status Gizi Baik, yaitu sebanyak sebanyak 51 ibu hamil $(82,3 \%)$ (LILA $\geq 23,5 \mathrm{~cm}$ ). Ibu hamil yang memiliki LILA <23,5 cm akan berisiko memiliki status gizi kurang dan mengalami KEK.

Pengukuran LILA biasanya digunakan untuk mengetahui risiko KEK pada ibu hamil sebagai skrining dan tidak 
bersifat pemantauan. Jika dibandingkan dengan LILA, pengukuran IMT tidak dapat digunakan untuk mendeteksi risiko KEK karena akan terjadi perubahan berat badan selama kehamilan. Dengan demikian, LILA relatif lebih stabil untuk mengetahui risiko KEK pada ibu hamil (Departemen Gizi dan Kesehatan Masyarakat, 2013).

Terdapat 11 responden $(17,7 \%)$ yang mengalami KEK, maka hal ini akan berdampak buruk terhadap bayi yang akan dilahirkan. Ibu hamil yang berisiko mengalami KEK akan diperkirakan melahirkan bayi dengan BBLR. Risiko yang ditimbulkan jika bayi dengan BBLR antara lain kematian, gizi kurang, gangguan pertumbuhan dan gangguan perkembangan anak (Supariasa, 2012).

Bagi ibu hamil yang kebutuhan gizinya tercukupi ditandai dengan bertambahnya berat badan selama kehamilan. Kenaikan berat badan selama hamil sebaiknya $10-12 \mathrm{~kg}$. Tetapi bagi ibu hamil yang gemuk dianjurkan kenaikan berat badan selama hamil hanya $7 \mathrm{~kg}$. Jika berat badan ibu hamil tidak normal maka berisiko terjadinya keguguran, lahir prematur, BBLR dan perdarahan saat persalinan (Kristiyanasari 2010).

Tabel 3. Hubungan Pengetahuan Ibu dengan Status Gizi Ibu Hamil di Puskesmas Tanjung Pinang Kota Jambi

\begin{tabular}{|c|c|c|c|c|c|c|c|c|}
\hline \multirow{3}{*}{ Pengetahuan } & \multicolumn{4}{|c|}{ Status Gizi Ibu Hamil } & \multirow{2}{*}{\multicolumn{2}{|c|}{ Total }} & \multirow{3}{*}{$\begin{array}{c}\text { Chi } \\
\text { Square }\end{array}$} & \multirow{3}{*}{ p-value } \\
\hline & \multicolumn{2}{|c|}{ Baik } & \multicolumn{2}{|c|}{ Kurang Baik } & & & & \\
\hline & $\mathrm{F}$ & $\%$ & $\mathrm{~F}$ & $\%$ & $\mathrm{~F}$ & $\%$ & & \\
\hline Baik & 30 & 96,8 & 1 & 3,2 & 31 & 100 & & \\
\hline Cukup & 13 & 100 & 0 & 0 & 13 & 100 & 24,915 & 0,00 \\
\hline Kurang & 8 & 44,4 & 10 & 55,6 & 18 & 100 & & \\
\hline Total & 51 & 82,3 & 11 & 17,7 & 62 & & & \\
\hline
\end{tabular}

Berdasarkan tabel 3 diperoleh hasil bahwa ibu yang memiliki pengetahuan baik mayoritas memiliki status gizi yang baik, yaitu sebanyak 30 responden $(96,8 \%)$. Begitu juga ibu yang memiliki pengetahuan kurang mayoritas memiliki status gizi yang kurang, yaitu sebanyak 10 responden $(55,6 \%)$.

Berdasarkan uji Chi Square diperoleh nilai $p$-value 0,000 . Oleh karena $p$-vale 0,000 $<0,05$ sehingga disimpulkan bahwa ada hubungan yang signifikan antara pengetahuan ibu dengan status gizi ibu hamil di Puskesmas Tanjung Pinang Kota Jambi Tahun 2016. Menurut pendapat Notoatmodjo (2010) bahwa hubungan antara pengetahuan, sikap, niat dan perilaku akan mempengaruhi keikutsertaan seseorang dalam suatu aktifitas tertentu. Adanya pengetahuan terhadap manfaat sesuatu hal, akan menyebabkan orang mempunyai sikap positif terhadap hal tersebut. Dalam hal ini ibu hamil yang memiliki sikap positif maka akan menerapkan hal-hal positif yang disarankan oleh petugas kesehatan, seperti memperhatikan konsumsi makanan yang bergizi untuk mencegah terjadinya KEK.

Dari hasil penelitian diperoleh bahwa sebagian besar hasil pengetahuan responden memiliki pengetahuan baik maka status gizinya pun juga baik. Hal ini disebabkan karena ibu hamil tersebut mengetahui dan memahami tentang pengertian gizi, manfaat gizi dan sumber-sumber gizi yang baik untuk ibu hamil sehingga mendorong ibu untuk menerapkan apa yang sudah diketahui ibu hamil tersebut. Maka dari itu ibu yang pengetahuan baik sebagian besar tidak mengalami KEK dan hanya 1 responden $(3,2 \%)$ yang mengalami KEK.

Hal ini sesuai dengan teori Hidayat (2007) bahwa pengetahuan merupakan suatu proses dengan menggunakan pancaindra yang dilakukan seseorang terhadap obyek tertentu sehingga menghasilkan keterampilan. Pengetahuan dapat membentuk keyakinan tertentu, sehingga seseorang berperilaku sesuai dengan keyakinan tersebut.

Aspek-aspek pengetahuan gizi diantaranya pangan dan gizi (pengertian, jenis, fungsi, sumber, akibat kekurangan). Kurangnya pengetahuan gizi mengakibatkan berkurangnya menerapkan informasi dalam kehidupan seharai-hari dan merupakan salah satu penyebab terjadinya gangguan gizi (Suhardjo, 2002). 
Pengetahuan kurang baik yang dimiliki responden tentang gizi selama kehamilan sebagian besar memiliki status gizi yang kurang baik juga, yaitu 10 ibu hamil $(55,6 \%)$ yang mengalami KEK. Rendahnya staus gizi maka akan berisiko terhadap timbulnya masalah. Timbulnya suatu masalah mengenai gizi diakibatkan karena ketidaktahuan atau kurangnya informasi yang diperoleh bagi ibu hamil mengenai gizi pada saat kehamilan. Ibu dengan kurang gizi dapat meningkatkan terjadinya resiko keguguran, kematian perinatal (kematian janin usia gestasi 22 minggu sampai usia 1 minggu pasca lahir) dan neonatal (bayi usia 0-28 hari) (Departemen Gizi dan Kesehatan Masyarakat, 2013).

Hal ini sesuai dengan pendapat Notoatmodjo (2010) bahwa informasi menjadi salah satu faktor eksternal untuk memperoleh pengetahuan seseorang. Pengetahuan individu sangat mempengaruhi perilaku sehatnya setiap hari. Ibu hamil yang tidak mendapatkan pengetahuan yang cukup tentang kehamilan seringkali mengalami masalah selama kehamilan. Pengetahuan ibu hamil juga mempengaruhi perilakunya dalam menjaga kehamilan. Ibu yang sedang mengalami kehamilan yang pertama biasanya sangat menjaga kehamilannya dengan cara rajin mengkonsumsi asupan-asupan gizi untuk kehamilannya

Pemenuhan gizi ibu hamil dipengaruhi oleh salah satu faktor, yaitu dukungan dari suami, keluarga, masyarakat. Tanpa dukungan dari orang terdekat maka suatu tujuan tidak akan tercapai dengan baik. Seperti dukungan materiil untuk memenuhi kebutuhan gizi ibu hamil. Apabila mengalami keterbatasan ekonomi maka hal tersebut juga akan berpengaruh terhadap kecukupan status gizi ibu hamil.

Penelitian ini sesuai dengan hasil penelitian Tenri (2012) tentang Hubungan Sosial Ekonomi dengan KEK menunjukkan pada pengeluaran pangan ada hubungan yang signifikan dengan KEK. Hal ini juga sesuai dengan pendapat Halim Surasih (2005) mengatakan bahwa faktor-faktor yang berhubungan dengan keadaan KEK pada ibu hamil adalah jumlah konsumsi energi, usia ibu hamil dan pendapatan keluarga serta pengetahuan ibu tentang gizi.

\section{KESIMPULAN DAN SARAN}

Berdasarkan hasil penelitian disimpulkan bahwa ada hubungan yang signifikan antara pengetahuan ibu dengan status gizi ibu hamil di Puskesmas Tanjung Pinang Kota Jambi Tahun 2016. Diharapkan bagi petugas Dinas kesehatan kota Jambi dapat mengembangkan beberapa kegiatan terkait promosi kesehatan mengenai status gizi pada ibu hamil. Bagi petugas Puskesmas Tanjung Pinang diharapkan dapat meningkatkan pemberian konseling, informasi dan edukasi (KIE) mengenai pengertian gizi, sumber makanan yang mengandung zat besi dan tanda yang kebutuhan gizi tercukupi bagi ibu hamil. Saran terhadap ibu hamil untuk tetap memenuhi kebutuhan nutrisi selama kehamilan secara beragam dan tidak harus mahal.

\section{REFERENSI}

Arikunto. (2010). Prosedur Penelitian Suatu Pendekatan Praktik. (Edisi Revisi). Jakarta : Rineka Cipta.

Arisman. (2007). Gizi Dalam Daur Ulang Kehidupan. Jakarta : ECG

Astri. (2011). Hubungan Pengetahuan Gizi dengan Kejadian KEK pada Ibu Hamil.

Badan Penelitian dan Pengembangan Kesehatan Kementrian Kesehatan RI. (2013). Riset Kesehatan

Departemen Gizi dan Kesehatan Masyarakat. (2013). Gizi dan Kesehatan Masyarakat. Jakarta : Rajawali Pers.

Dinas Kesehatan Kota Jambi. (2013). Profil Dinas Kesehatan Kota Jambi Tahun 2013.

Dinas Kesehatan Kota Jambi. (2014). Profil Dinas Kesehatan Kota Jambi Tahun 2014.

Hidayat, A. Aziz Alimul. (2007). Metode Penelitian dan Teknik Analisis Data. Jakarta : Salemba Medika.

Kristiyanasari, Weni. (2010). Gizi Bagi Ibu Hamil. Yogyakarta : Nuha Medika.

Notoatmodjo, Soekidjo. (2010). Metodologi Penelitian Kesehatan. Jakarta : Rineka Cipta.

Sandjaja, dkk. (2009). Kamus Gizi. Jakarta : PT Kompas Media Nusantara.

Suhardjo. (2002). Perencanaan Pangan dan Gizi. Jakarta : Bumi Aksara. 
Sulistyoningsih, Haryani. (2011). Gizi untuk Kesehatan Ibu dan Anak. Yogjakarta : Graha Ilmu.

Supariasa, dkk. (2012). Penilaian Status Gizi. Jakarta : EGC.

Surasih. (2005). Faktor-faktor yang mempengaruhi Kejadian KEK. Jurnal Tesis, Universitas Negeri Semarang.

Tenri. (2012). Hubungan Sosial Ekonomi dengan Kekurangan Energi Kronik (KEK) di Desa Pasaman Jawa Barat. Jurnal Tesis, Universitas Hasanuddin.

UNICEF. (2012). Ringkasan Kajian Gizi. Jakarta : Unicef Indonesia. 